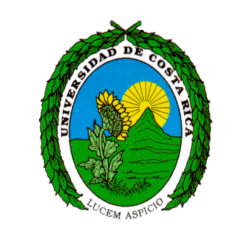

\title{
EKG 6-2014: Marcapaso Migratorio.
}
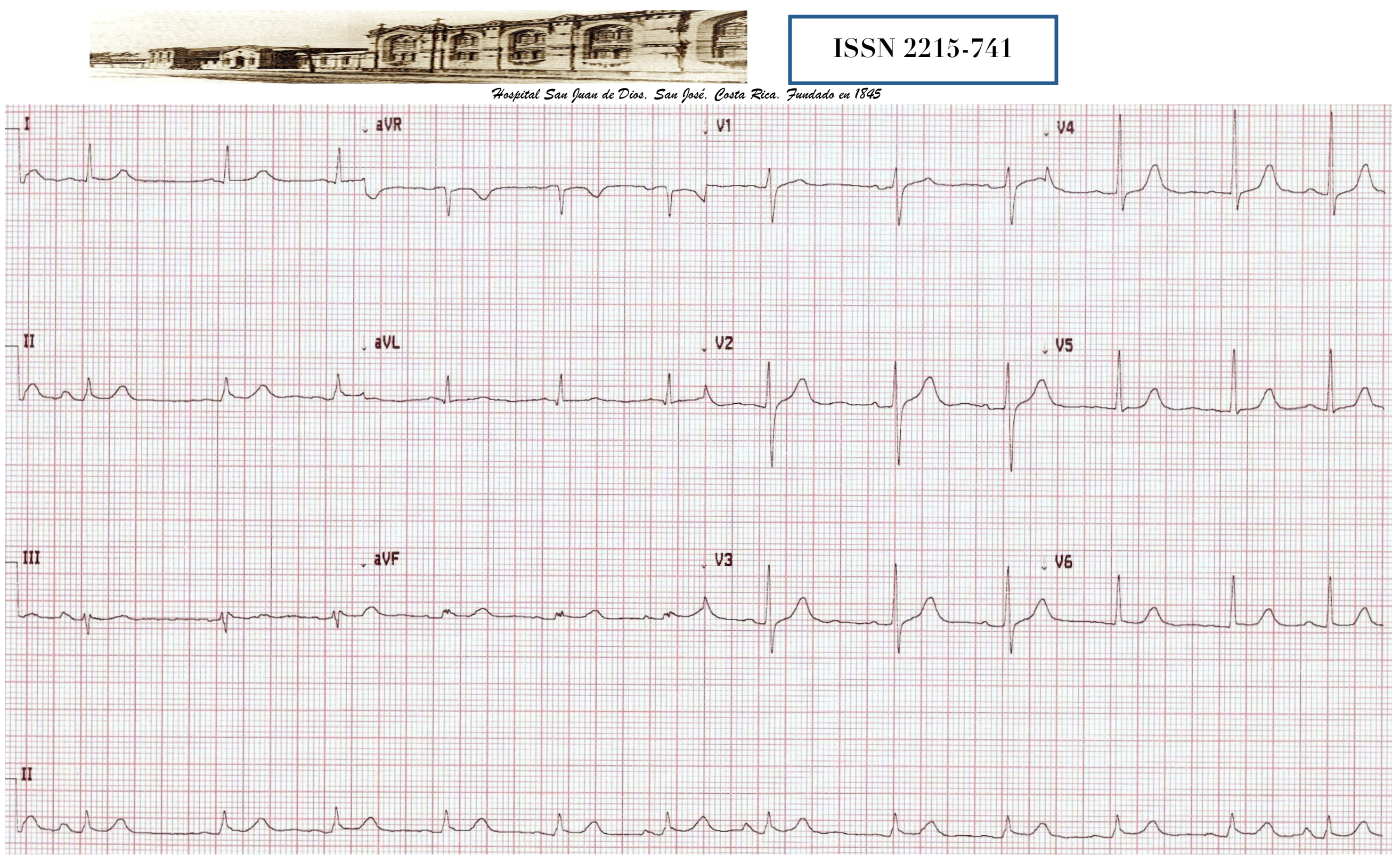